\title{
Mucosal gastrin concentration, molecular forms of gastrin, number and ultrastructure of G-cells in patients with duodenal ulcer ${ }^{1}$
}

\author{
W. CREUTZFELDT, R. ARNOLD, C. CREUTZFELDT, AND N. S. TRACK \\ From the Division of Gastroenterology and Metabolism, Department of Medicine, University of Göttingen, \\ Germany
}

SUMMARY The mean antral immunoreactive gastrin (IRG) concentration of 38 duodenal ulcer (DU) patients was significantly higher $(35.9 \pm 5.2 \mu \mathrm{g} / \mathrm{g})$ than that of 21 controls $(15.9 \pm 2.6 \mu \mathrm{g} / \mathrm{g})$. Also the mean IRG concentration in the proximal duodenal mucosa of $15 \mathrm{DU}$ patients $(3.2 \pm$ $0.8 \mu \mathrm{g} / \mathrm{g}$ ) was higher (but not significantly) than that of 10 controls $(1.8 \pm 0.5 \mu \mathrm{g} / \mathrm{g})$. The number of G-cells in the antral mucosa of 58 DU patients and in the duodenal mucosa of 29 DU patients was not larger than that of controls. The distribution of immunoreactivity in gastrin components has been investigated in the antral and duodenal mucosa of six DU patients and six controls. In the antral mucosa the mean percentage of G-17 was $93.3 \%$ in DU patients and $92.0 \%$ in controls. G-34 amounted to $4.0 \%$ in DU patients and to $5.0 \%$ in controls. The G-34 percentage in the duodenal mucosa was higher (however not significantly) in the DU patients than in the controls $(50 \cdot 1 \%$ versus $35.8 \%)$. Ultrastructurally, the antral G-cells of DU patients had a significantly lower density index of their secretory granules suggesting higher functional activity. It is concluded that the exaggerated serum IRG response of DU patients to different stimuli is not a consequence of an increased G-cell mass.

In duodenal ulcer (DU) patients there is a significantly higher increase in serum immunoreactive gastrin (IRG) after a protein rich meal (Korman et al., 1971; McGuigan and Trudeau, 1973; Stern and Walsh, 1973; Mayer et al., 1974), insulin hypoglycaemia (cf. Stadil, 1974), or sham feeding (Mayer et al., 1974) than in healthy controls. The exaggerated IRG response of DU patients may result from: an increased number of antral and/or duodenal G-cells, an increased antral and/or duodenal gastrin content or an increased release of highermolecular-weight-gastrin-components characterized by a longer half-life.

The gastrin concentration of antral mucosa has been investigated using bioassay (Blair et al., 1962; Emås et al., 1971) and radioimmunoassay (Creutzfeldt et al., 1974; Hughes and Hernandez, 1975; Malmström and Stadil, 1975). The results were contradictory. Few data have been published on the number of G-cells in the antral mucosa. Also these ${ }^{1}$ Dedicated to Professor W. Bargmann on his 70th birthday.
Received for publication 28 June 1976 results were contradictory (cf. Creutzfeldt $e t$ al., 1975a).

This report describes the IRG concentration, the molecular forms of IRG, and the number and ultrastructural appearance of G-cells in the antral and duodenal bulb mucosa of patients with duodenal ulcer and in healthy controls. Preliminary data have been reported at recent symposia (Creutzfeldt et al., 1974; Arnold et al., 1974; Creutzfeldt et al., 1975b).

\section{Methods}

SUBJECTS

Gastric and/or duodenal mucosal samples were investigated from 63 patients with duodenal ulcer (DU) and 23 control subjects. The mean age of the DU patients ( 57 males and six females) was 39 years (range 21-68) and of the control subjects (13 males and 10 females) 28 years (range 19-58). All DU patients had a characteristic history with relapsing ulcer disease. The diagnosis was made by radiographs and gastroduodenoscopy or during operation. 
The control subjects consisted of three groups: (1) 13 volunteers (eight males, five females) without known diseases of the gastrointestinal tract; (2) five patients (two males, three females) with dyspeptic complaints; (3) five patients (three males, two females) undergoing duodenopancreatectomy (Whipple's procedure) because of an insulinoma (two cases) or chronic pancreatitis (three cases).

All control subjects had normal basal and pentagastrin-stimulated gastric secretion. Group 2 and 3 had normal radiographs of the stomach and the duodenal bulb and normal findings with respect to stomach and duodenum at endoscopy or laparotomy. The volunteers were not subjected to barium meal investigation but underwent gastroduodenoscopy. They were medical students and technicians who were fully informed about the object and the risk of the investigation. All endoscopies and tissue sampling were performed after intravenous injection of diazepam with a prograde ACMI fibrescope by the same investigator. As the results in these three groups did not differ, they have been pooled in one control group. Simultaneous biopsies of antral and duodenal mucosa both for immunohistology and gastrin extraction were not done in all subjects. Therefore, the respective number of cases is noted in the Tables and Figures.

TISSUE SAMPLING

Specimens of antral or duodenal mucosa were obtained either by forceps biopsy during gastroscopy or during operation. Antral mucosa was excised from 1 to $3 \mathrm{~cm}$ proximal to the pylorus. Duodenal mucosa was excised from the duodenal bulb. The samples were either fixed immediately for histological or ultrastructural investigation or stored in a deep-freeze $\left(-30^{\circ} \mathrm{C}\right)$ until assay and weighed before homogenization. The average weight of the forceps biopsies was as follows: antral mucosa 6.1 $\mathrm{mg} \pm 0.4$ (range $2.4-12.3 \mathrm{mg}$ ); duodenal mucosa $4.3 \mathrm{mg} \pm 0.5$ (range 0.8-6.7 mg). The average weight of the surgical biopsies: antral mucosa $235.2 \mathrm{mg} \pm$ 68.9 (range 58.9-871.2 mg); duodenal mucosa $152 \cdot 8 \mathrm{mg} \pm 36 \cdot 7$ (range $37 \cdot 0-321 \cdot 1 \mathrm{mg})$.

\section{ESTIMATION OF MUCOSAL IRG} CONCENTRATION

For extraction, the samples were weighed, quickly thawed in a water bath at $27^{\circ} \mathrm{C}$ and homogenized using an Ultraturrax homogenizer in $0.01 \mathrm{M}$ phosphate buffer, $\mathrm{pH} 7 \cdot 5$, supplemented with $0.15 \mathrm{M}$ sodium chloride and $0.03 \mathrm{M}$ sodium azide. The homogenate was placed in a water bath at $100^{\circ} \mathrm{C}$ for 10 minutes and centrifuged. The IRG level was determined by radioimmunoassay in the supernatant in a series of dilutions from 1:100 to 1:100000.
Sensitivity and specificity of the radioimmunoassay was described in detail elsewhere (Mayer et al., 1974). Antiserum 118/2/3, which was used for all estimations, had three times lower affinity towards human G-34 than towards equimolar amounts of G-17. It did not cross-react with highly purified CCK-PZ (a gift from Dr V. Mutt, Stockholm) in concentrations up to $50 \mathrm{ng} / \mathrm{ml}$. The recovery of synthetic gastrin added to tissue samples was above $90 \%$.

\section{Fractionation of total IRG}

Antral and duodenal bulb mucosa extracts were chromatographed upon Sephadex G-50 fine columns $(1 \times 100 \mathrm{~cm})$ in $0.01 \mathrm{M}$ phosphate buffer, $\mathrm{pH} 7 \cdot 5$, supplemented with $0.15 \mathrm{M}$ sodium chloride and $0.03 \mathrm{M}$ sodium azide. The column flow rate was $18 \mathrm{ml}$ per hour. Successive $1.0 \mathrm{ml}$ fractions were collected and assayed for immunoreactive gastrin content. The column was calibrated with natural human big (G-34) and little (G-17) gastrins (kindly provided by Professor R. A. Gregory, Liverpool). G-34 eluted from $120-135 \mathrm{ml}$ and G-17 from $150-165 \mathrm{ml}$ from the column. The elution positions of G-45 (component I) and G-13 (component IV) were calculated from published column profiles (Rehfeld and Stadil, 1973; Rehfeld et al., 1974). The sensitivity of the column was $1 \mathrm{ng}$ for G-17 and G-34. The column was loaded with 5-10 ng equivalent IRG.

\section{MMUNOHISTOLOGY}

Tissue samples were fixed in Bouin's fluid and embedded in paraffin. Sections $5 \mu$ thick, cut vertically to the surface, were deparaffinized and stained for gastrin as described previously (Creutzfeldt et al., 1971). For evaluating the number of G-cells the stained sections were examined with a Zeiss-Photo-Microscope II. The size of the area used for counting antral G-cells $(0.35 \times 0.23 \mathrm{~mm})$ encompasses the midzone of the antral mucosa, where antral G-cells are predominantly situated in man (Fig. 1). The size of the area used for counting G-cells in the duodenal bulb mucosa was 6.6 times larger $(0.89 \times 0.60 \mathrm{~mm})$ and encompasses the whole region between surface of mucosa and lamina muscularis propria, because duodenal G-cells are not concentrated in a certain zone (Fig. 2). Only sections revealing the whole area between surface and lamina muscularis propria were evaluated. At least 10 subsequent areas from three different sections of antral and duodenal bulb mucosa were counted. In the case of very small mucosal specimens more than three sections were evaluated. The mean number of antral and duodenal G-cells counted in each case was called the G-cells/area. 


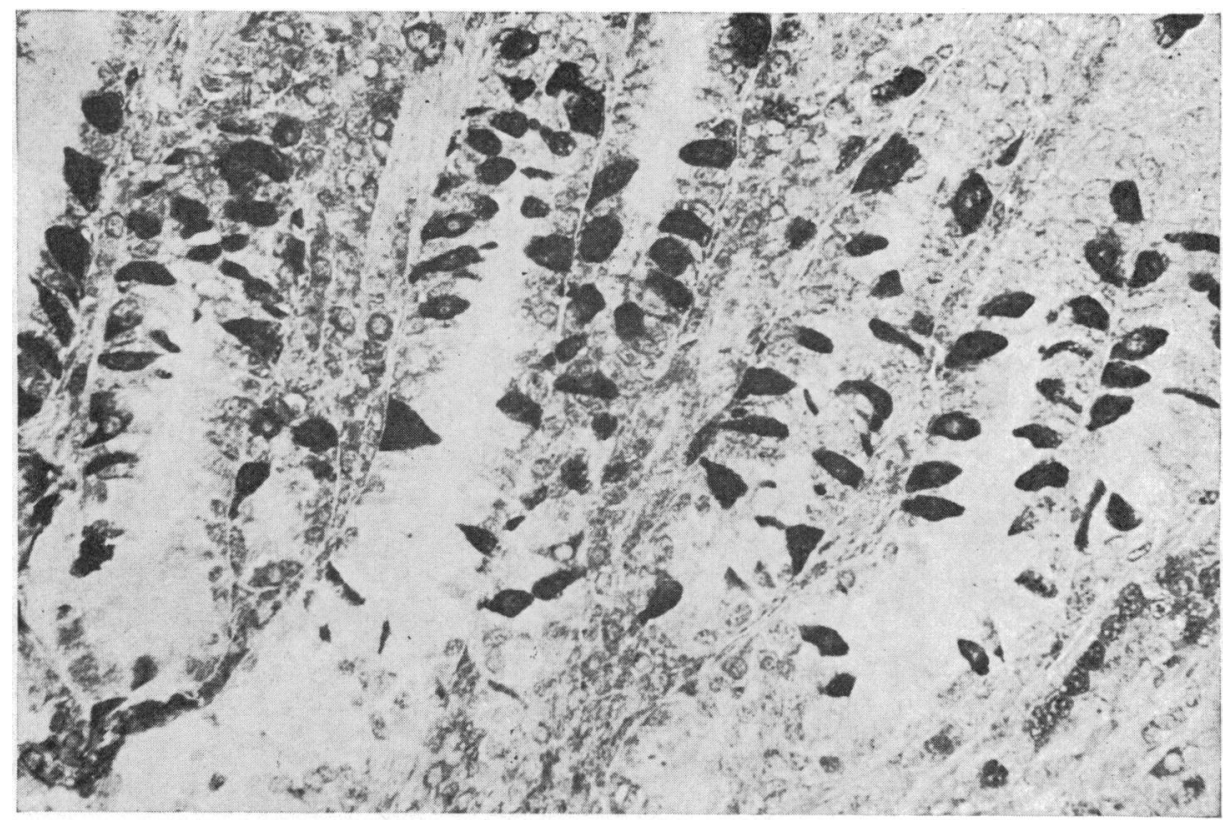

Fig. 1 The size of the area used for counting antral G-cells $(0.35 \times 0.23 \mathrm{~mm})$ encompasses the midzone of the antral mucosa. The number of G-cells found in this area is expressed as ' $G$-cells/area'. Bouin fixation. Paraffin embedding. Incubation with 1/50 diluted antigastrin serum; after washing, incubation with 1/50 diluted peroxidase labelled anti-rabbit-y-globulin from sheep. $\times 400$.

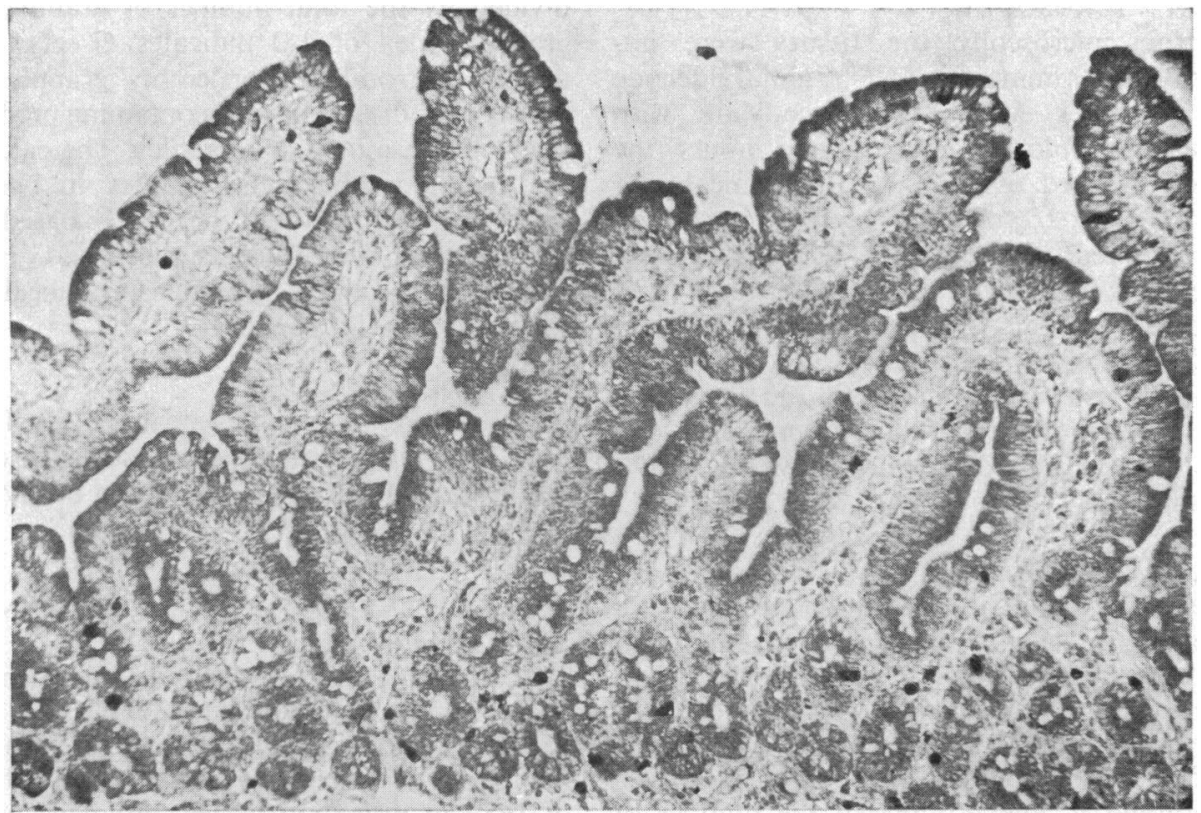

Fig. 2 The size of the area used for counting G-cells in the duodenal bulb mucosa $(0.89 \times 0.60 \mathrm{~mm})$ encompasses the region between surface of mucosa and lamina muscularis propria. In contrast with antral G-cells, duodenal G-cells are sparse. (Technique as in Fig. 1.) $\times 160$. 


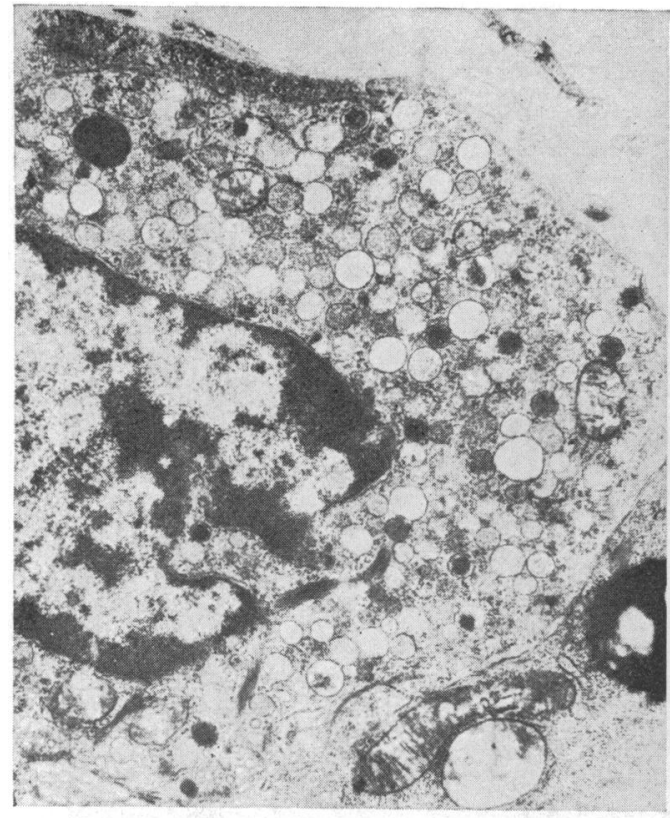

(a)

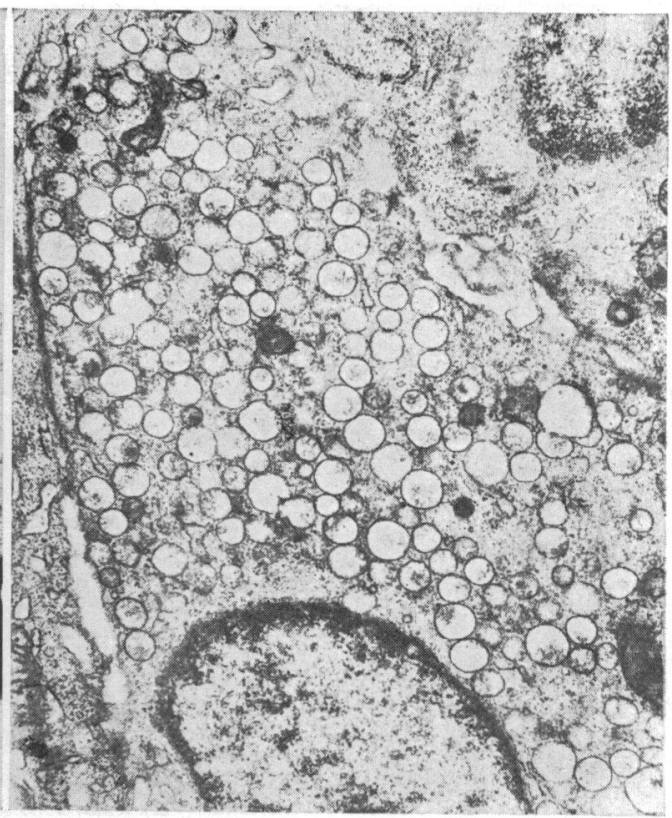

(b)

Fig. 3 Calculation of G-cell granule density indices in two different $G$-cells $(a)$ and $(b)$. A full granule $(F)$ scores 4, intermediate-full (IF) 3, intermediate-empty (IE) 2, and an empty $(E)$ granule 1. The product of the number of each granule type observed multiplied by its scoring factor was calculated separately for the four different granule types, summarized and divided by the total number of granules. (a) G-cell scoring $2 \cdot 12$. (b) G-cell scoring $1 \cdot 22$.

\section{ELECTRON MICROSCOPY}

For electron microscopy the tissues were immediately fixed by immersion in $3 \%$ glutaraldehyde buffered with $0.1 \mathrm{M}$ sodium cacodylate with $0.03 \%$ calcium chloride. After three hours the tissues were washed overnight in the same buffer and transferred to $2 \%$ osmium tetroxide in sodium cacodylate buffer. After rinsing the tissues were dehydrated in a graded series of acetone and embedded in Vestopal. Ultrathin sections were cut on an LKB-Ultramicrotome, picked up on formvarcoated copper grids and stained with uranyl acetate and lead citrate (Coggeshall and Venable, 1965). The sections were viewed in a Zeiss EM $9 \mathrm{~S}$ with a built-in condenser.

\section{G-cell granule density index}

In an attempt to obtain a quantitative assessment of the overall granule population in the different G-cell activity states a G-cell granule density index, based upon the electron density of granule content, was devised. A 'full' granule scored 4, an 'intermediate full' 3 , an 'intermediate empty' 2 , and an 'empty' granule 1. The product of the number of each granule type observed within one single cell and its scoring factor was calculated separately for the four different granule types, summarized, and divided by the total number of granules. Thus, a granule index of 1-2 indicates G-cells containing mainly electron lucent or 'empty' granules, while an index of 3 indicates G-cells containing predominantly electron dense or 'full' granules. The calculation of the G-cell granule density index in two different G-cells is demonstrated in Fig. 3. Based upon the evaluation of $10 \mathrm{G}$-cells per case, the G-cell granule density indices were calculated in 11 healthy volunteers and nine DU patients.

\section{STATISTICAL ANALYSIS}

All values are presented as means \pm SEM. Student's $t$ test for unpaired values and least square correlation coefficient was used for calculation of P-values.

\section{Results}

IRG CONCENTRATION IN ANTRAL AND

DUODENAL MUCOSA

Mucosal IRG concentration varied considerably both in controls and DU patients. As immediate freezing of the excised specimens was not easy to realize (especially in surgical biopsies) the stability of IRG in untreated tissue specimens was investigated. Biopsies of antral mucosa obtained from the same prepyloric region of man, dog and rat were kept at room temperature or $+4^{\circ} \mathrm{C}$ up to 24 hours 
Table 1 Antral mucosal IRG concentration ( $\mu \mathrm{g} / \mathrm{g}$ wet weight) in different specimens obtained from the same prepyloric region and kept for different time intervals until freezing

\begin{tabular}{|c|c|c|c|c|c|c|c|c|c|c|c|}
\hline \multirow[b]{2}{*}{ Case no: } & \multicolumn{6}{|c|}{ Man* } & \multicolumn{2}{|c|}{$\operatorname{Dog}^{*}$} & \multicolumn{3}{|l|}{ Rat $\dagger$} \\
\hline & $I$ & II & III & IV & $\boldsymbol{V}$ & $V I$ & $I$ & $I I$ & $I$ & II & $I I I$ \\
\hline $\begin{aligned} 0 \\
15 \mathrm{~min} \\
30 \mathrm{~min} \\
1 \mathrm{~h} \\
2 \mathrm{~h} \\
5 \mathrm{~h} \\
24 \mathrm{~h}\end{aligned}$ & $\begin{array}{l}6.5 \\
9.4 \\
8.0\end{array}$ & $\begin{array}{r}8.3 \\
23.2 \\
8.8\end{array}$ & $\begin{array}{r}4 \cdot 2 \\
12 \cdot 6 \\
7 \cdot 7\end{array}$ & $\begin{array}{l}8 \cdot 7 \\
6 \cdot 1 \\
8 \cdot 3\end{array}$ & $\begin{array}{r}11.6 \\
35.0 \\
7.5\end{array}$ & $\begin{array}{r}4.9 \\
11.3 \\
10 \cdot 0\end{array}$ & $\begin{array}{l}11 \cdot 1 \\
17 \cdot 4 \\
- \\
- \\
- \\
11 \cdot 6\end{array}$ & $\begin{array}{l}2 \cdot 3 \\
4 \cdot 3 \\
- \\
- \\
- \\
- \\
4 \cdot 0\end{array}$ & $\begin{array}{r}13 \cdot 6 \\
- \\
12 \cdot 8 \\
7 \cdot 6 \\
11 \cdot 5 \\
14 \cdot 4\end{array}$ & \begin{tabular}{r}
$12 \cdot 8$ \\
\multicolumn{1}{c}{-} \\
$8 \cdot 9$ \\
$12 \cdot 8$ \\
$9 \cdot 0$ \\
$6 \cdot 2$
\end{tabular} & $\begin{array}{l}8 \cdot 3 \\
- \\
4 \cdot 8 \\
5 \cdot 1 \\
3 \cdot 2 \\
2 \cdot 1\end{array}$ \\
\hline
\end{tabular}

* Kept at room temperature.

†Kept at $+4^{\circ} \mathrm{C}$.

Table 2 IRG concentration and number of G-cells in antral and duodenal mucosa of controls and patients with duodenal ulcer

\begin{tabular}{|c|c|c|c|c|}
\hline & $\begin{array}{l}\text { Antral IRG } \\
(\mu \mathrm{g} / \mathrm{g} \pm S E M)\end{array}$ & $\begin{array}{l}\text { Duodenal IRG } \\
(\mu g / g \pm S E M)\end{array}$ & $\begin{array}{l}\text { Antral } G \text {-cells } \\
\text { per area } \pm S E M\end{array}$ & $\begin{array}{l}\text { Duodenal G-cells } \\
\text { per area } \pm S E M\end{array}$ \\
\hline $\begin{array}{l}\text { Controls } \\
\text { Duodenal ulcer }\end{array}$ & $\begin{array}{l}15 \cdot 9 \pm 2 \cdot 6 \\
(n=21) \\
35 \cdot 93 \pm 5 \cdot 2 * \\
(n=38)\end{array}$ & $\begin{array}{l}1 \cdot 8 \pm 0.5 \\
(n=10) \\
3 \cdot 2 \pm 0.8 \\
(n=15)\end{array}$ & $\begin{array}{l}38 \cdot 7 \pm 3 \cdot 4 \\
(n=18) \\
41 \cdot 2 \pm 2 \cdot 6 \\
(n=58)\end{array}$ & $\begin{array}{l}10 \cdot 6 \pm 1.5 \\
(n=9) \\
9.9 \pm 1.0 \\
(n=29)\end{array}$ \\
\hline
\end{tabular}

*Significant difference from controls $(P<0.005)$.

(Table 1). In all species the concentration was not uniform for the same individual. However, the concentration did not decrease with the time elapsing until freezing. Also the method of freezing (liquid nitrogen, dry ice, or simple deposition in the deep freeze) did not influence the IRG concentration. From these results it is concluded that the wide range of IRG concentration is due to irregular distribution of the G-cells.
Accordingly, a correlation between the IRG concentration of sample $I$ and $I I$ in 31 subjects of whom two biopsies were obtained was only low $(r=0.5092 ; \mathrm{P}<0.01)$. The mean IRG concentration in the antral and duodenal mucosa of controls and DU patients is listed in Table 2. The IRG concentration of $38 \mathrm{DU}$ patients was significantly $(P<0.005)$ higher than in the antral mucosa of 21 controls. However, the overlap was considerable.

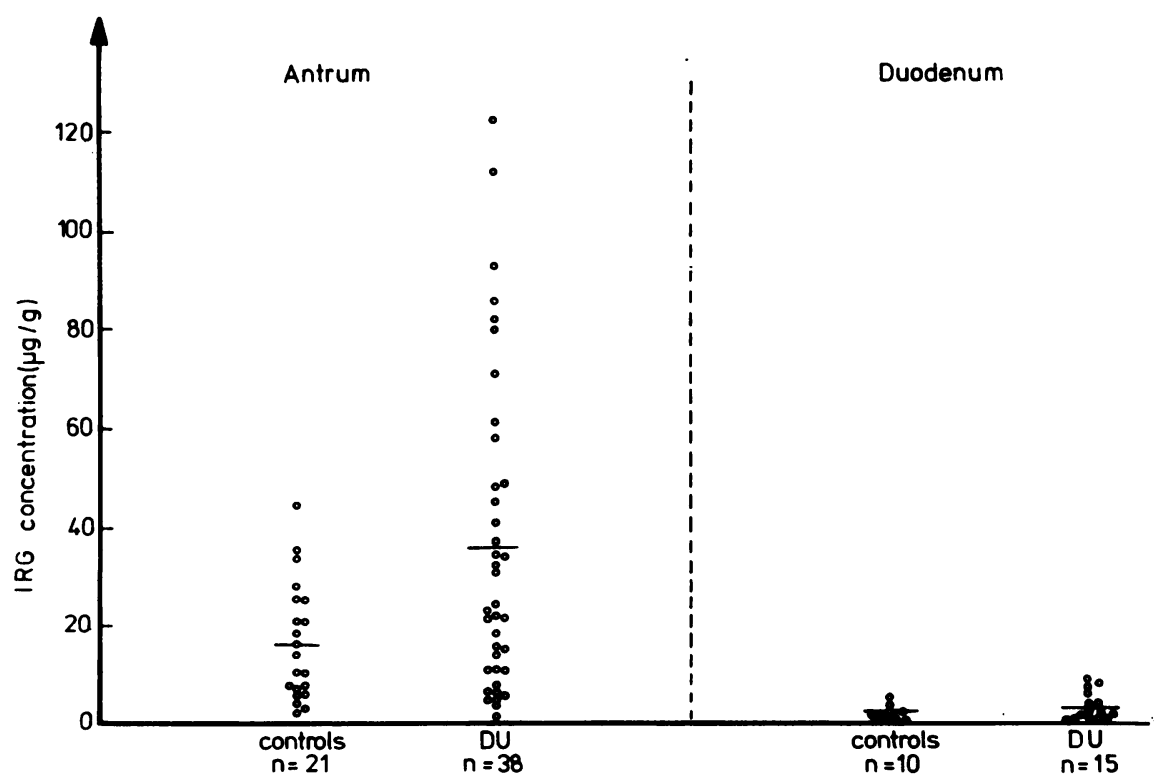

Fig. 4 IRG concentration in antral and duodenal mucosa of DU patients and controls. 


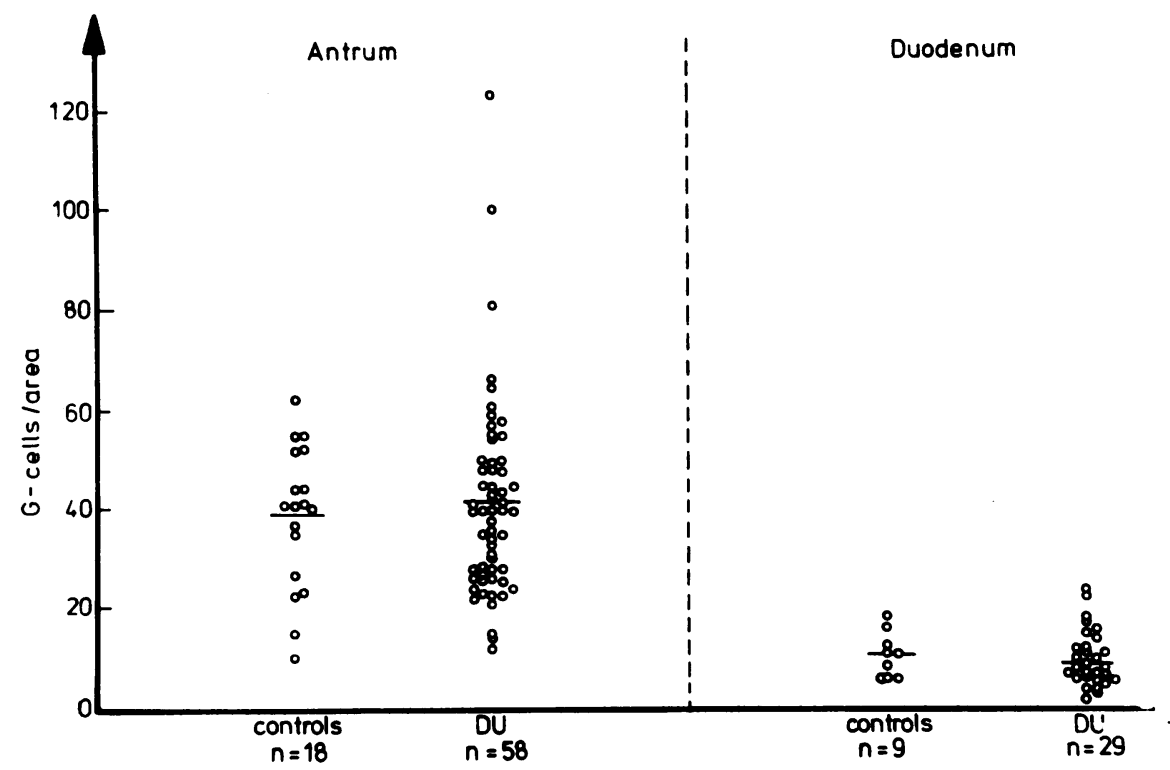

Fig. 5 Number of G-cells in antral and duodenal mucosa of DU patients and controls. The area in which the duodenal G-cells are counted is 6.6 times larger than in the antrum.

Only one-third of the DU patients had an IRG concentration which was higher than the highest control value (Fig. 4). This tendency was apparent also in the duodenal IRG concentration (Table 2, Fig. 4). However, the difference was not statistically significant.

No difference could be found between surgical and endoscopic biopsies. The cases with high mucosal IRG concentration did not have especially high values for basal or stimulated gastric acid output or for fasting or meal stimulated serum IRG levels.

G-CELL NUMBER IN ANTRAL AND

DUODENAL MUCOSA

The number of G-cells in antral and duodenal mucosa was identical in controls and DU patients (Fig. 5). The number of G-cells was significantly less in the duodenal than in the antral mucosa. Figure 5 does not reflect this relationship correctly because the area counted for G-cells in the duodenal mucosa was 6.63 times larger than in the antral mucosa. The number of G-cells in antral and duodenal mucosa obtained during endoscopy did not differ significantly from the findings in the much larger samples obtained during operation.

No relationship existed between IRG concentration and the number of G-cells in antral or duodenal mucosa both in controls and DU patients. Cases with a high number of antral or duodenal G-cells did not have raised levels for basal or stimulated gastric acid output or for fasting or meal stimulated serum IRG levels.

\section{FRACTIONATION OF MUCOSAL IRG}

The distribution of immunoreactivity in gastrin components was investigated in extracts of antral and duodenal mucosa of six control subjects and six DU patients. The Sephadex G-50 gel filtration patterns are listed in Table 3 (gastric mucosal extracts) and Table 4 (duodenal mucosal extracts). Two major immunoreactive components corres-

Table 3 Distribution of immunoreactivity in gastrin components $(\%)$ in antral mucosal extracts from controls and $\mathrm{DU}$ patients

\begin{tabular}{|c|c|c|c|c|}
\hline & $G-45$ & $G-34$ & $G-17$ & $G-13$ \\
\hline \multicolumn{5}{|l|}{ Controls } \\
\hline $\begin{array}{l}\text { Ha. (insulinoma) } \\
\text { K1. (chron. }\end{array}$ & 一 & 4 & 96 & - \\
\hline pancreatitis) & 一 & 9 & 82 & 9 \\
\hline Br. (insulinoma) & - & 4 & 96 & - \\
\hline Ko. (insulinoma) & 2 & 5 & 81 & 12 \\
\hline Bo. (volunteer) & - & - & 100 & - \\
\hline Sch. (volunteer) & - & 3 & 97 & - \\
\hline$\overline{\mathbf{x}}$ & & $5 \cdot 0$ & $92 \cdot 0$ & \\
\hline SEM & & $1 \cdot 0$ & $3 \cdot 3$ & \\
\hline \multicolumn{5}{|l|}{ DU patients } \\
\hline Bro. & 一 & - & 100 & - \\
\hline Man. & - & 1 & 99 & - \\
\hline Hen. & - & 3 & 97 & - \\
\hline Kan. & - & 8 & 80 & 12 \\
\hline Cas. & 2 & 2 & 90 & 6 \\
\hline Kes. & - & 6 & 94 & - \\
\hline$\overline{\mathbf{x}}$ & & $4 \cdot 0$ & $93 \cdot 3$ & \\
\hline SEM & & $1 \cdot 3$ & 3.0 & \\
\hline
\end{tabular}


Table 4 Distribution of immunoreactivity in gastrin components $(\%)$ in duodenal mucosal extracts from controls and DU patients

\begin{tabular}{lllll}
\hline & $G-45$ & $G-34$ & $G-17$ & $G-13$ \\
\hline $\begin{array}{lllll}\text { Controls } \\
\text { Ha. (insulinoma) }\end{array}$ & - & 29 & 71 & - \\
K1. (chron. & & & & \\
$\quad$ pancreatitis) & - & 27 & 55 & 18 \\
Br. (insulinoma) & - & 41 & 59 & - \\
Ko. (insulinoma) & - & 35 & 65 & - \\
Go. (chron. & & & & \\
$\quad$ pancreatitis) & - & 47 & 45 & 8 \\
\& $\quad$ & & $35 \cdot 8$ & $59 \cdot 0$ & \\
SEM & & $3 \cdot 7$ & $4 \cdot 4$ & \\
DU patients & - & 34 & 56 & - \\
Bro. & - & 68 & 32 & - \\
Man. & - & 44 & 56 & - \\
Hen. & - & 47 & 47 & 6 \\
Kan. & - & 30 & 70 & - \\
Cas. & & 78 & 20 & - \\
Barc. & & 50.1 & 47.2 & \\
SEM & & $7 \cdot 8$ & $7 \cdot 2$ & \\
\hline
\end{tabular}

ponding to the elution pattern of G-17 and G-34 were found in the mucosal extracts of all cases, both controls and DU patients. Component I (G-45) and G-13 were detected only in several cases (Fig. 6).

The predominant IRG component in the antral and duodenal mucosa of controls and DU patients was G-17. Ninety-two per cent (range $81-100 \%$ ) of the total IRG was present as G-17 in the antral mucosa of controls and $93.3 \%$ (range $80-100 \%$ ) in the antral mucosa of DU patients. Only $5 \%$ (range $3-9 \%$ was present as G-34 in the antral mucosa of controls and $4.0 \%$ (range $1.8 \%$ ) in the antral mucosa of DU patients. Thus, the patterns of IRG in antral mucosa of controls and DU patients were identical.

In the mucosa of the proximal duodenum G-34 amounted to $35.8 \%$ (range $27-47 \%$ ) of the total IRG in controls and to $50.1 \%$ (range $30-78 \%$ ) in DU patients. Correspondingly, G-17 was only $59.0 \%$ (range $45-71 \%$ ) of the total IRG in controls and $47.2 \%$ (range $22.70 \%$ ) in DU patients. However, the higher percentages of G-34 in the duodenal mucosa of DU patients did not reach statistical significance.

\section{ULTRASTRUCTURE OF ANTRAL G-CELLS}

The secretory granules of antral G-cells display a broad scale of varying electron density. In DU patients electron lucent 'empty' granules seemed to predominate in comparison with controls. By applying a morphometric method for assessment of the granule population (Fig. 3), a significant lower index of the granule density was calculated for the DU patients (Table 5). In the same DU patients the IRG concentration of the antral mucosa was significantly higher than in the controls, while the

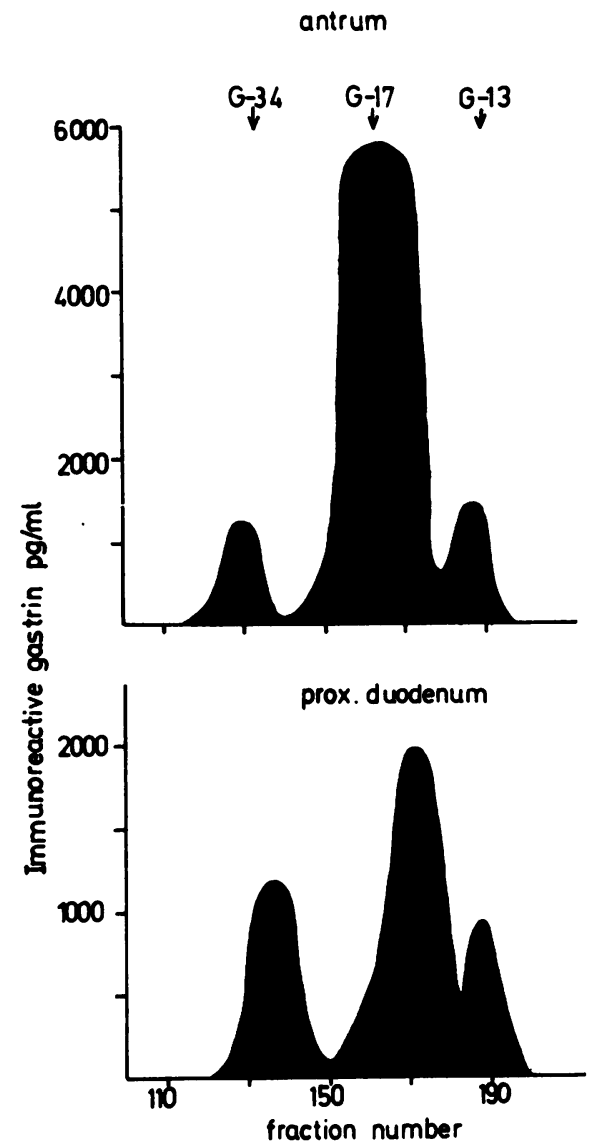

Fig. 6 Sephadex G-50 gel filtration patterns of immunoreactive gastrin in mucosa extracts of antrum and proximal duodenum from a control subject (patient $\mathrm{Kl}$. of Tables 3 and 4). The void volume of the column started at fraction 60. No significant IRG levels were detected before fraction 105 .

Table 5 G-cell granule density, IRG concentration and number of G-cells in antral mucosa of controls and DU patients

\begin{tabular}{llll}
\hline & $\begin{array}{l}\text { G-cell } \\
\text { granule density } \\
\text { index }\end{array}$ & $\begin{array}{l}\text { IRG } \\
\text { concentration } \\
(\mu \mathrm{g} / \mathrm{g})\end{array}$ & $\begin{array}{l}\text { G-cells per } \\
\text { area }\end{array}$ \\
\hline $\begin{array}{l}\text { Controls (n }=11) \\
\begin{array}{l}\text { DU patients } \\
(\mathrm{n}=9)\end{array}\end{array}$ & $2.52 \pm 0.14$ & $17.5 \pm 3.6$ & $37.2 \pm 3.5$ \\
\hline
\end{tabular}

*Significant difference from controls $(P<0.025)$, $+(P<0.005)$.

number of G-cells was not different (Table 5).

This finding suggests that G-cells with electron dense secretory granules do not necessarily contain more gastrin than G-cells with electron lucent granules. 


\section{Discussion}

A substantial variation of the mucosal IRG concentration has been observed by different investigators (Berson and Yalow, 1971; Creutzfeldt et al., 1971; Jackson et al., 1972; Malmström and Stadil, 1975). Already Berson and Yalow (1971) have discussed the reasons which may be responsible for this: initial rapid loss of IRG in excised unfrozen tissue or random variation among a small number of samples. In this investigation the IRG concentration was stable for many hours in three different species (Table 1). Even rapid freezing in liquid nitrogen did not change the result. This finding contradicts the conclusion of Malmström and Stadil (1975) who state that gastrin is rapidly degraded in untreated specimens. According to our investigation, the variation in the IRG concentration is mainly due to an uneven distribution of the G-cells in the mucosa. This conclusion agrees with the morphological findings: an identical variation has been found regarding the number of G-cells stained by immunohistology (Fig. 5). In this case IRG degradation could not have influenced the results because the tissue had been fixed immediately. Thus, single values of IRG concentration in antral or duodenal mucosa may be misleading and multiple biopsies are necessary for evaluating an individual case. However, this sampling error can be disregarded if groups of patients are compared.

In a group of 38 patients with duodenal ulcer a significantly higher IRG concentration has been found in the antral mucosa. This result disagrees with published investigations using a radioimmunoassay for gastrin. Malmström and Stadil (1975) compared 12 controls with 28 DU patients and Hughes and Hernandez (1975) 32 controls with 18 DU patients. The absolute values of Malmström and Stadil (1975) were higher, but both groups found no differences between controls and DU patients. The disagreement between these results and our findings is difficult to explain. The IRG concentration of the controls was in the same range in all investigations. The higher mean value of the 38 DU patients in our series resulted from 11 cases with values higher than the highest control values. These $11 \mathrm{DU}$ patients were not different from the whole group regarding basal or stimulated gastric acid secretion, fasting or meal-stimulated serum IRG levels, and number of antral G-cells.

The IRG concentration of the duodenal mucosa amounted to roughly one-tenth of that of the antral mucosa both in controls and in DU patients. In the latter the mean value was higher but this did not reach statistical significance.

Contrary to the differences of the IRG content, the number of G-cells identified by immunohistology in antral and duodenal mucosa was identical in controls and DU patients. This finding does not confirm suggestions of more abundant G-cells in the antral mucosa of DU patients (Pearse et al., 1970; Pearse and Bussolati, 1970; Polak et al., 1972). However, systematic investigations on this question have not yet been published. In only three of $58 \mathrm{DU}$ patients of this series did the number of G-cells exceed the range of the 18 controls and only one of these three had an antral IRG concentration in the upper range. From this finding it can be concluded that the high IRG concentration found in one-third of the DU patients is not due to an increased G-cell mass.

A greater G-cell mass or antral G-cell hyperplasia has been described as cause for recurrent ulcer disease with fasting hypergastrinaemia (Polak et al., 1972; Ganguli et al., 1974). However, this entity seems to be extremely rare (Hansky, 1974) and has not yet been found in this laboratory. The number of G-cells in the mucosa of the duodenal bulb was much smaller than in the antral mucosa (less cells were counted in an area which was 6.6 times larger than in the antrum). This corresponds well with the much smaller IRG concentration in duodenal mucosa.

Berson and Yalow (1971) have described the distribution of the major gastrin components in the antral and duodenal mucosa. They found in the antrum predominantly G-17 (component III) and in the duodenum predominantly G-34 (component II). It has not been investigated systematically whether the molecular forms of gastrin differ between DU patients and controls. No significant differences were found in the antral (Table 3) and duodenal (Table 4) mucosa between six controls and six DU patients. The pattern in the antral mucosa was identical in the two groups. The higher percentage of G-34 in the mucosa of the duodenal bulb in the DU patients did not reach statistical significance. The percentages reported here for G-34 are underestimations of the real values because the antigastrin serum used in these studies has a $70 \%$ lower affinity, on a molar basis, for G-34 compared with that for G-17 (Mayer et al., 1974). The findings do not support recent suggestions of Stadil et al. (19/5). These authors found in pooled sera increased levels of G-17 in DU patients. Such a difference does not correspond with the mucosal patterns of gastrin components described here.

The discrepancy between normal G-cell number in antral and duodenal mucosa together with elevated mucosal IRG concentration suggests a higher gastrin content for the single G-cell. According to the secretory cycle of the G-cell formulated by Forss- 
mann and Orci (1969), the number of electron dense secretory granules of the G-cells should be higher in DU patients than in controls. Forssmann and Orci (1969) had observed in cats and rats that, in the fasting state, the G-cells contained predominantly electron dense secretory granules and after feeding predominantly electron lucent membraneous sacs. This had been interpreted as discharge of the stored hormone from the granules into the cytoplasm and from there into the bloodstream. However, these morphological findings have not been supported by hormone estimation by Forssmann and Orci. In recent rat experiments a low granule density index of the antral G-cells was found together with an elevated antral IRG concentration and increased levels of serum IRG after stimulation by feeding (Creutzfeldt et al., 1975b). From this finding it had been concluded that a low granule density index denotes only that gastrin has been released recently from granule stores; however, as gastrin biosynthesis occurs very rapidly, it gives no indication of the total amount of gastrin in the cell. As demonstrated in Table 5, the DU patients had a significantly lower granule density index than the controls and at the same time a significantly higher IRG content of the antral mucosa without an increase in number of G-cells. It cannot be decided yet whether the IRG in the G-cells is present in the electron lucent 'empty' granules or in a non-granular form in the cytoplasm.

In conclusion, the exaggerated IRG response of DU patients to different stimuli is not the consequence of an increased G-cell mass. The G-cells are not increased in the antral or duodenal mucosa (Table 1) and the antrum of DU patients is not larger than that of controls (Capper et al., 1966). Also different molecular forms of gastrin do not explain the higher IRG serum levels after stimulation in DU patients. However, the low density index of the secretory granules and the elevated mucosal IRG concentration (Table 5) may be interpreted as signifying higher functional activity of the G-cells in DU patients. Such an increased activity could be due to a defect in autoregulation of gastrin release and gastric acid secretion at low $\mathrm{pH}$ (Walsh et al., 1975) or to a higher vagal tone.

This work was supported by the Deutsche Forschungsgemeinschaft, Bonn-Bad Godesberg, grant Cr 20/7. The authors thank Miss E. Bothe, Miss N. Bufe, Miss H. Dörler, Miss A. Nesslinger, and Miss J. Weigt for their expert technical assistance and Dr H. Bauer (Chirurgische Poliklinik, Universität München) for collecting and preserving surgical specimens of antral and duodenal mucosa.

\section{References}

Arnold, R., Creutzfeldt, C., Track, N. S., and Creutzfeldt, W. (1974). Gastrin und Duodenalulcus. Verhandlungen der Deutschen Gesellschaft für Innere Medizin, 80, 368-377.

Berson, S. A., and Yalow, R. S. (1971). Nature of immunoreactive gastrin extracted from tissues of gastrointestinal tract. Gastroenterology, 60, 215-222.

Blair, E. L., Harper, A. A., and Reed, J. D. (1962). An assay technique for gastrin. Journal of Physiology, 163, 47P-48P.

Capper, W. M., Butler, T. J., Buckler, K. G., and Hallett, C. P. (1966). Variation in size of the gastric antrum: measurement of alkaline area associated with ulceration and pyloric stenosis. Annals of Surgery, 163, 281-291.

Coggeshall, R., and Venable, J. H. (1965). A simplified lead citrate stain for use in electron microscopy. Journal of Cell Biology, 25, 407-408.

Creutzfeldt, W., Arnold, R., Creutzfeldt, C., Feurle, G., and Ketterer, H. (1971). Gastrin and G-cells in the antral mucosa of patients with pernicious anemia, acromegaly and hyperparathyroidism and in a Zollinger-Ellison tumour of the pancreas. European Journal of Clinical Investigation, 1, 461-479.

Creutzfeldt, W., Creutzfeldt, C., and Arnold, R. (1974). Gastrin-producing cells. In Endocrinology of the Gut, pp. 35-62. Edited by W. Y. Chey and F. P. Brooks. Charles R. Slack: Thorofare, New Jersey.

Creutzfeldt, W., Creutzfeldt, C., and Arnold, R. (1975a). The gastrin-producing cells under normal and pathological conditions. Rendiconti di Gastroenterologia, 7, 93-109.

Creutzfeldt, W., Track, N. S., Creutzfeldt, C., and Arnold R. (1975b). The secretory cycle of the G-cell: ultrastructural and biochemical investigations of the effect of feeding in rats. In Gastrointestinal Hormones, pp. 197-211. Edited by J. C. Thompson. University of Texas Press: Austin.

Emås, S., Borg, I., and Fyrö, B. (1971). Antral and duodenal gastrin activity in non-ulcer and ulcer patients. Scandinavian Journal of Gastroenterology, 6, 39-43.

Forssmann, W. G., and Orci, L. (1969). Ultrastructure and secretory cycle of the gastrin-producing cell. Zeitschrift für Zellforschung, 101, 419-432.

Ganguli, P. C., Polak, J. M., Pearse, A. G. E., Elder, J. B., and Hegarty, M. (1974). Antral-gastrin-cell hyperplasia in peptic-ulcer disease. Lancet, 1, 583-586.

Hansky, J. (1974). Antral-gastrin-cell hyperplasia in peptic ulcer disease. (Letter.) Lancet, 1, 1344.

Hughes, W., and Hernandez, A. (1975). Antral gastrin concentration and meal stimulated gastrin release in patients with vagotomy and pyloroplasty. (Abstract.) Gastroenterology, 68, 917.

Jackson, B. M., Reeder, D. D., Searcy, J. R., Watson, L. C., Hirose, F. M., and Thompson, J. C. (1972). Correlation of the surface $\mathrm{pH}$, histology, and gastrin concentration of gastric mucosa. Annals of Surgery, 176, 727-731.

Korman, M. G., Soveny, C., and Hansky, J. (1971). Serum gastrin in duodenal ulcer. Part I: Basal levels and effect of food and atropine. Gut, 12, 899-902.

McGuigan, J. E., and Trudeau, W. L. (1973). Differences in rates of gastrin release in normal persons and patients with duodenal-ulcer disease. New England Journal of Medicine, 288, 64-66.

Malmström, J., and Stadil, F. (1975). Measurement of immunoreactive gastrin in gastric mucosa. Scandinavian Journal of Gastroenterology, 10, 433-439.

Mayer, G., Arnold, R., Feurle, G., Fuchs, K., Ketterer, H., Track, N. S., and Creutzfeldt, W. (1974). Influence of feeding and sham feeding upon serum gastrin and gastric acid secretion in control subjects and duodenal ulcer 
patients. Scandinavian Journal of Gastroenterology, 9, 703-710.

Pearse, A. G. E., and Bussolati, G. (1970). Immunofluorescence studies of the distribution of gastrin cells in different clinical states. Gut, 11, 646-648.

Pearse, A. G. E., Coulling, I., Weavers, B., and Friesen, S. (1970). The endocrine polypeptide cells of the human stomach, duodenum and jejunum. Gut, 11, 649-658.

Polak, J. M., Stagg, B., and Pearse, A. G. E. (1972). Two types of Zollinger-Ellison syndrome: immunofluorescent, cytochemical and ultrastructural studies of the antral and pancreatic gastrin cells in different clinical states. Gut, 13, 501-512.

Rehfeld, J. F., and Stadil, F. (1973). Gel filtration studies on immunoreactive gastrin in serum from Zollinger-Ellison patients. Gut, 14, 369-373.

Rehfeld, J. F., Stadil, F., and Vikelsøe, J. (1974). Immuno- reactive gastrin components in human serum. Gut, 15, 102-111.

Stadil, F. (1974). Gastrin and insulin hypoglycaemia. A review of studies in gastrin determination and hypoglycaemic release of gastrin in man. Scandinavian Journal of Gastroenterology, 9, suppl. 23, 1-49.

Stadil, F., Rehfeld, J. F., Christiansen, L. A., and Malmström, J. (1975). Patterns of gastrin components in serum during feeding in normal subjects and duodenal ulcer patients. Scandinavian Journal of Gastroenterology, 10, 863-868.

Stern, D. H., and Walsh, J. H. (1973). Gastrin release in postoperative ulcer patients: evidence for release of duodenal gastrin. Gastroenterology, 64, 363-369.

Walsh, J. H., Richardson, C. T., and Fordtran, J. S. (1975). pH-dependence of acid secretion and gastrin release in normal and ulcer subjects. Journal of Clinical Investigation, 55, 462-468. 